\title{
Pharmacological basis for the medicinal use of polyherbal formulation and its ingredients in cardiovascular disorders using rodents
}

\author{
Abdul Malik ${ }^{1,2}$, Malik Hassan Mehmood ${ }^{1 *}$, Hajra Channa ${ }^{1,3}$, Muhammad Shoaib Akhtar ${ }^{2}$
} and Anwarul-Hassan Gilani ${ }^{1,4}$

\begin{abstract}
Background: A compound herbal formulation $\left(\mathrm{POL}_{4}\right)$ has been used in the indigenous system of medicine to treat cardiometabolic disorders like diabetes and associated hypertension. $\mathrm{POL}_{4}$ and most of its constituents have not been studied widely for its therapeutic use in hypertension. This study is aimed to determine the efficacy and possible insight into mechanism(s) for the medicinal use of $\mathrm{POL}_{4}$ and its ingredients in hypertension.

Methods: The aqueous methanolic extracts of $\mathrm{POL}_{4}\left(\mathrm{POL}_{4}\right.$. Cr) and its components [Cichorium intybus (Ci.Cr), Gymnema sylvestre (Gs.Cr), Nigella sativa (Ns.Cr) and Trigonella foenum graecum (Tfg.Cr)] were tested for blood pressure lowering activity in anaesthetized Sprague-Dawley rats. To assess the vasomodulatory effect, isolated tissue experiments were performed on rat aortic strips using isometric force transducer coupled with PowerLab data acquisition system.

Results: Administration of $\mathrm{POL}_{4}$ to rats caused a dose-dependent (1-100 mg/kg) fall in mean arterial pressure (MAP) with maximum effect of $85.33 \pm 1.76 \%$ at $100 \mathrm{mg} / \mathrm{kg}$, similar to the effect of verapamil. All ingredients of $\mathrm{POL}_{4}$ also decreased blood pressure with varying efficacy in following order $\mathrm{Ns} . \mathrm{Cr} \cong \mathrm{Ci}$.Cr $>\mathrm{Tfg} . \mathrm{Cr}>\mathrm{Gs}$.Cr. In rat aortic preparations, $\mathrm{POL}_{4}$ and its ingredients inhibited $\mathrm{K}^{+}(80 \mathrm{mM})$-induced contractions, $\mathrm{Ci}$.Cr was the most potent followed by Ns.Cr $>\mathrm{Tfg}$.Cr $>\mathrm{Gs}$.Cr $\cong \mathrm{POL}_{4}$. Against phenylephrine (P.E) contractions, Ci.Cr and Tfg.Cr exhibited complete relaxation, while $\mathrm{POL}_{4}$. Cr, Gs.Cr and Ns.Cr showed vasomodulatory effect. The $\mathrm{Ca}^{++}$antagonist activity was confirmed when $\mathrm{POL}_{4}$ and its ingredients shifted $\mathrm{Ca}^{++}$concentrations-response curves to the right in a manner similar to that of verapamil. On baseline of rat aorta, the parent formulation and its ingredients (except Tfg.Cr) exhibited partially phentolamine $(1 \mu \mathrm{M})$-sensitive vasoconstriction.

Conclusion: These data show that $\mathrm{POL}_{4}$ and its constituents possess blood pressure lowering activity mediated through inhibition of $\mathrm{Ca}^{++}$influx via membranous $\mathrm{Ca}^{++}$channels and receptor (a-adrenergic) operated pathways. Thus, this study provides a rationale to the medicinal use of $\mathrm{POL}_{4}$ and its constituents in hypertension.
\end{abstract}

Keywords: $\mathrm{POL}_{4}$, Antihypertensive, Vasomodulatory, $\mathrm{Ca}^{++}$antagonist, a-adrenergic antagonist

\footnotetext{
* Correspondence: hassan.mehmood@aku.edu;

malikhassan.mehmood@gmail.com

${ }^{1}$ Natural Product Research Division, Department of Biological and Biomedical

Sciences, Faculty of Health Sciences, Medical College, The Aga Khan

University, Stadium Road, P.O. Box 3500, Karachi 74800, Pakistan

Full list of author information is available at the end of the article
} 


\section{Background}

Cardiovascular disorders (CVDs) are huge disease burden worldwide [1]. Hypertension, dyslipidemia and endothelial dysfunctions are the major pathologies of commonly prevailing CVDs [2]. Hypertension is a silent killer, which is known to cause around 9.8 million deaths annually [3]. Pakistan is one of the South Asian countries where around 18 million people at the age of fifteen and above are living with hypertension. Out of these, around $70 \%$ population is even unaware about the disease status, while only $3 \%$ successfully control blood pressure with regular medication [4-6]. Multiple antihypertensive therapeutic agents are available to combat this deadly disorder, however, their high cost and life-long use of the medication along with associated multiple adverse effects ultimately results in patient unaffordability and poor-compliance [7]. The current strategy to defeat chronic non-communicable disorders is changing throughout the world. The use of alternative approaches, particularly medicinal remedies and supplements $[8,9]$, have become popular over the past three decades. Around $80 \%$ of people worldwide rely on natural products [10] for therapeutic purpose. Treating chronic disorders like hypertension or diabetes, the herbal remedies are considered relatively safe, affordable and easily accessible. The relative safety of natural products when used for longer duration might be because of the presence of synergistic and/or side effects neutralizing constituents inbuilt in medicinal herbs [11]. In our settings due to cultural acceptance, people prefer to use herbal remedies for the treatment of various chronic ailments like gastrointestinal [12], respiratory tract [13], endocrine (diabetes) [14] and cardiovascular disorders [15]. Despite using individual herbs to treat different ailments, there are multiple evidences supporting therapeutic use of compound formulations in the treatment of hypertension and dyslipidemia. Some of the combined formulations like Sharbat Abresham, Hab Fishar for hypertension, Arq-SheerMorakkab as cardiotonic, Muffrahe-Barid-Sada and Arq-Gazar Ambari as anti-palpitant [16] are used in indigenous system of medicine in Pakistan. $\mathrm{POL}_{4}$, an indigenous polyherbal formulation containing four edible medicinal herbs (Cichorium intybus L., Gymnema sylvestre R. Br., Nigella sativa L., and Trigonella foenum graecum L.) is also popular for its medicinal use in cardiometabolic disorders, however, no study is available to rationalize its medical use in cardiometabolic disorders like hypertension.

The ingredients of $\mathrm{POL}_{4}$ : C. intybus (family: Asteraceae) commonly called Chicory or Kasni, G. sylvestre (family: Asclepiadaceae) known as Gurmar booti, N. sativa (family: Ranunculaceae) referred as Black cumin or Kalonji and $T$. foenum graecum (family: Fabaceae) vernacularly called as Fenugreek or Methi are popular for their medicinal use as cardiotonic, antihypertensive and cadio-depressant [17]. $C$. intybus (coumarins, sterols, tannins, triterpene cichoridiol, lupeol, sesquiterpene glycoside, caffeic acid and cichotyboside) [18], G. sylvestre (gymnemasides anthraquinone, stigmasterol, betaine, quercitol and gymnemagenin) [19], $N$. sativa (thymoquinone, $\alpha$-pinene, p-cymnene, carvacrol, terpineol, nigellicimine and nigellidine) [20] and T. foenum graecum (trigonelline, cholin, gentian, carpaine and 4-hydroxyisoleucine and diosgenin) [21] have been found enriched with variety of phytochemicals. Most of the determined phytochemicals on the part of the components of $\mathrm{POL}_{4}$ are also known for their diverse health benefits including their effectiveness in cardiovascular disorders [22-27]. Though detailed studies are lacking to justify the cardiovascular benefits of $\mathrm{POL}_{4}$ and its ingredients, the available data is providing some support to individual components $\{C$. intybus $[27,28], G$. sylvestre $[19,29]$ and $T$. foenum graecum $[30,31]\}$ for their utility in cardiovascular disorders with exception of $N$. sativa which has been studied widely. Despite the availability of ample data on $N$. sativa and its constituents (thymoquinone, $\alpha$-pinene and p-cymene) for their effectiveness in hypertension [24-26, $32-34]$, the effect of its seed extract with holistic picture on vascular and atrial preparations is yet to be determined for its modulating role on vascular resistance and cardiac output. This study has been designed to provide an evidence to the medicinal use of $\mathrm{POL}_{4}$ and its ingredients in cardiovascular disorders like hypertension with a prime objective to determine the blood pressure lowering effects and the possible insight into mechanism(s). While the secondary objective was to compare the efficacy of ingredients with the parent formulation to justify the use of this formulation in hypertension and/or to suggest modification in its current composition. The in-vivo assays were carried out in rat as per their similarity with human cardiovascular system, which are commonly employed worldwide to determine antihypertensive efficacy of the test compounds [35-37], while isolated tissue experiments were conducted in rat (aorta) and guinea-pig (atria) tissues.

\section{Methods \\ Preparation of aqueous-methodic extracts of $\mathrm{POL}_{4}$ and its ingredients}

The plant materials were purchased from "Rehmania Pinsar Store" Sargodha and the samples were identified by Dr. Muhammad Amin Ullah Shah, Assistant Professor of Botany, Department of Botany, University of Sargodha, Sargodha, Pakistan. The respective samples have been submitted in the herbarium at University of Sargodha with voucher numbers as: [seeds of $N$. sativa (Malik-632), C. intybus (Malik-633), T. foenum graecum (Malik-634) and leaves of G. sylvestre (Malik-635)]. The individual plant materials and in combination $\left(\mathrm{POL}_{4}\right)$ were subjected for extraction. For preparation of the crude extract, $1 \mathrm{~kg}$ of powder of each plant material and $1 \mathrm{~kg}$ of $\mathrm{POL}_{4}$ (all ingredients in equal proportions) were 
soaked, respectively, in aqueous methanol (30: 70) for 3 days with occasional shaking. The methanol of analytical grade was purchased from Merck KGaA, Darmstadt, Germany. The first filtrate obtained was subjected to filter using muslin cloth and Whatman (Maidstone, UK) No.1 filter paper simultaneously. The procedure was repeated twice and all filtrates were combined and evaporated under rotary evaporator (BUCHI, Switzerland) [38]. The filtrates were then air dried and the respective percentage yields were calculated for the crude extracts of polyherbal formulation $\mathrm{POL}_{4} \cdot \mathrm{Cr} \quad(16 \% \mathrm{w} / \mathrm{w}), C$. intybus, Ci.Cr (11\% w/w), G. sylvestre, Gs.Cr (18\% w/w), N. sativa, Ns.Cr $(12 \% \mathrm{w} / \mathrm{w})$ and T. foenum graecum, Tfg.Cr $(17.5 \% \mathrm{w} / \mathrm{w})$.

\section{Drugs and chemicals}

Verapamil hydrochloride, potassium chloride, acetylcholine chloride, phenylephrine, phentolamine, norepinephrine, isoproterenol and calcium chloride were purchased from Sigma Chemical Company, St. Louis, MO, U.S.A. Glucose, sodium chloride, magnesium sulphate, magnesium chloride, potassium dihydrogen phosphate, sodium bicarbonate and sodium dihydrogen phosphate were from E. Merck, Darmstadt, Germany. All chemicals used were of the highest purity grade. Physiological salt solutions were prepared fresh in distilled water on the day of experiment, while stock solutions of all chemicals and extracts were constituted in distilled water/saline and stored at $-20{ }^{\circ} \mathrm{C}$, while required dilutions were prepared fresh on the day of the experiment.

\section{Animals, diet and experimental protocol}

The Sprague-Dawley (SD) rats weighing 180-250 g and locally bred guinea pigs weighing 450-550 g healthy of either sex housed at the animal house of Aga Khan University, Karachi, were used in this study. Animals were either sourced from PCSIR (Pakistan Council of Scientific and Industrial Research, Karachi or Dow University of Health Sciences Karachi and have also been managed to be bred at the animal house of Aga Khan University. The animals were housed in a temperature maintained facility $\left(23 \pm 5{ }^{\circ} \mathrm{C}, 55 \pm 5 \%\right.$, relative humidity) with 12-hr light/dark cycle, kept in plastic cages with sawdust (renewed at every two days). Animals had free access to standard diet $[(\mathrm{g} / \mathrm{kg})$ : flour 380 , fiber 380 , molasses 12 , sodium chloride 5.8 , nutrivet-L 2.5 , potassium metabisulphate 1.2 , vegetable oil 38 , fish meal 170 and powdered milk 150] and tap water, and were acclimatized for 5 to 7 days before starting experiment. The experimental protocols were approved (57-ECACUBBS-15) by Ethics Committee for Animal Care and Use (ECACU) of the Aga Khan University, Karachi.

\section{Phytochemical screening}

Phytochemical screening of the crude extract of $\mathrm{POL}_{4}$ and its constituents were carried out for the presence of flavonoids, tannins, saponins, alkaloids, anthraquinones and coumarins by using an earlier described method with slight modification [39].

\section{Determination of total phenolic contents}

Quantitative determination of phenolics contents of the aqueous methanolic extracts of compound herbal formulation $\mathrm{POL}_{4}$ and its ingredients were carried out by an earlier method [40] with slight modification. Briefly, $1 \mathrm{ml}$ of Folin-Ciocalteu reagent was added to the test material solution containing $1 \mathrm{mg}$ in a volumetric flask and adjusted to $46 \mathrm{ml}$ with distilled water. After $3 \mathrm{~min}$, $3 \mathrm{ml}$ of $\mathrm{Na}_{2} \mathrm{CO}_{3}$ (2\%) was added to the mixture, which was afterward kept for $2 \mathrm{~h}$ at room temperature with continuous shaking on a shaker. The absorbance was measured at $760 \mathrm{~nm}$ by using spectrophotometer (Model DU-730, Beckman Instruments Inc, Palo Alto, CA, USA). Total phenolic content of the test materials were expressed as mg equivalent of gallic acid equivalent/g of the dried extract.

\section{Determination of total flavonoid contents}

Amount of total flavonoid compounds of the aqueous methanolic extracts of $\mathrm{POL}_{4}$ and its ingredients were determined as described previously [41]. Around $1.5 \mathrm{ml}$ of the test material solution was added to an equal volume of solution of $2 \% \mathrm{AlCl}_{3} \cdot 6 \mathrm{H}_{2} \mathrm{O}$ in methanol. The mixture was vigorously shaken and absorbance was recorded at $367 \mathrm{~nm}$ after $10 \mathrm{~min}$ of incubation. The absorption measured using a spectrophotometer (Model DU 730). Flavonoid contents were expressed as $\mathrm{mg}$ of quercetin equivalent/g of the extract.

In-vivo blood pressure measurement in anaesthetized rats SD rats (180-250 g) of either sex were used by following an earlier method [42]. The animals were randomly selected and were anesthetized with an intraperitoneal injection of thiopental sodium (purchased from Pharmacy of Aga Khan University Hospital, Karachi, Pakistan) at a dose of $40-70 \mathrm{mg} / \mathrm{kg}$ body weight. The arterial blood pressure was recorded by cannulating carotid artery filled with heparinized saline to a disposable blood pressure transducer (model MLT 0699) attached with bridge amplifier and a PowerLab data acquisition system (ADInstruments, Australia). Jugular vein was cannulated to inject different test material(s) to the animal. Before injecting $0.9 \% \mathrm{NaCl}$ $(0.1 \mathrm{ml} / \mathrm{kg}$, saline) or equal volume of test substance(s) to rats, a period of about $10-15 \mathrm{~min}$ was given for stabilization. Heparin was purchased from Pharmacy of Aga Khan University Hospital, Karachi, Pakistan. Between each injected dose, the arterial pressure was allowed to 
return to normal or resting level. Prior to the assessment of the effect of the different doses $(1-100 \mathrm{mg} / \mathrm{kg})$ test material(s), standard drugs responses like acetylcholine $(1 \mathrm{mg} / \mathrm{kg})$ and norepinephrine $(1 \mathrm{mg} / \mathrm{kg})$ were given intravenously (jugular vein) to obtain the control responses. The difference between the steady state values before and after injection was recorded as the mean arterial pressure (MAP). MAP was calculated by using the formula $\mathrm{PP}=\mathrm{SP}$-DP where PP-pulse pressure, SP-systolic pressure and DP-diastolic pressure.

\section{Isolated rat aortic preparation}

SD rats (180-250 g) of either sex were used randomly in this study and were anesthetized using Isoflurane (2-5\% $\mathrm{v} / \mathrm{w}$ ) by inhalation in a closed chamber until achievement of deep anesthesia. Isoflurane was purchased from Pharmacy of Aga Khan University Hospital, Karachi, Pakistan. Dissection was carried out to isolate thoracic aortae and the aorta was cut into rings of around 2 to $3 \mathrm{~mm}$. The rings were mounted in $5 \mathrm{ml}$ water bath containing Kreb's solution at $37{ }^{\circ} \mathrm{C}$ and carbogen $\left[\mathrm{O}_{2}\right.$ (95\%) and $\left.\mathrm{CO}_{2}(5 \%)\right]$ was continuously supplied. The Kreb's solution was prepared freshly on the day of experiment which consists of following ingredients in $\mathrm{mM}: \mathrm{NaCl}$ 118.2, $\mathrm{KCl}$ 4.7, $\mathrm{KH}_{2} \mathrm{PO}_{4}$ 1.3, $\mathrm{MgSO}_{4}$ 1.2, $\mathrm{NaHCO}_{3}$ 25.0, Glucose 11.7 and $\mathrm{CaCl}_{2} 2.5$ with $\mathrm{pH}$ 7.4. A pre-load of $2 \mathrm{~g}$ was provided as baseline tension and each tissue preparation was allowed to incubate for a period of $60 \mathrm{~min}$. The changes in isometric tension were recorded and analyzed using the force transducer model (50-7905, Harvard Apparatus, USA), linked with a Trans-bridge model TBM4M and PowerLab data acquisition system (ML845, ADInstrument). The tissues were stabilized with phenylephrine (P.E $1 \mu \mathrm{M})$. The test materials $(0.003$ to $10 \mathrm{mg} / \mathrm{ml})$ were tested for vasorelaxant potential against P.E $(1 \mu \mathrm{M})$ and high $\mathrm{K}^{+}$ $(80 \mathrm{mM})$-induced contractions. For confirmation of calcium channel blocking (CCB) like activity, the $\mathrm{Ca}^{++}$ concentration-response curves (CRCs) were produced in $\mathrm{Ca}^{++}$-free medium in the absence and presence of test material(s) to observe if there is a non-parallel shift in the CRCs of $\mathrm{Ca}^{++}$towards right with suppression of maximum response [15]. To determine the presence of vasoconstrictor constituents in test material(s), experiments were performed on resting baseline tone of the aortic preparations. First, tissues were stabilized with P.E until steady-state baseline tone; the vasoconstrictor effect of the test material(s) was presented as percent of P.E- induced contraction and has also been reproduced in the presence of phentolamine ( $\alpha$-adrenergic receptor antagonist) to identify its sensitivity with phentolamine.

\section{Isolated guinea-pig atria}

Guinea-pigs of either sex were euthanized followed by anesthesia with Isoflurane. Dissection was carried out quickly and carefully to isolate right atria. The isolated atria was cleaned and mounted in $20 \mathrm{ml}$ water bath containing Kreb's solution maintained at $32{ }^{\circ} \mathrm{C}$. The bathing solution was bubbled continuously with carbogen. The atria as applied $1 \mathrm{~g}$ resting tension and allowed to beat normally as it contains the pacemaker cells. Atrial tissue was allowed for an equilibrium period of around $30 \mathrm{~min}$ before application of any test material(s) or standard $\operatorname{drug}(\mathrm{s})$ like isoproterenol $(1 \mu \mathrm{M})$ and acetylcholine $(1 \mu \mathrm{M})$. A force-displacement transducer coupled to PowerLab data acquisition system (ADInstrument, Australia) was used to record the tension changes in the tissues [43].

\section{Data analysis}

The experimental data presented as mean \pm S.E.M (standard error of mean), $\mathrm{n}=$ number of experiments and $\mathrm{EC}_{50}$ (median effective concentration) values were reflecting as the geometric means with $\mathrm{CI}$ (confidence intervals) of $95 \%$. Concentration response curves were constructed and analyzed by non-linear regression followed by sigmoidal curves. For determination of significant differences, one way ANOVA (analysis of variance) followed by Dunnet's test or two-way ANOVA followed by Bonferroni's post-test correction or unpaired $t$-test were applied. $P$ values $<0.05$ were taken as significantly different. GrpahPad Prism (Version 4.00) software was used for constructing graphs and analysis.

\section{Results}

\section{Phytochemical screening}

Qualitative phytochemical screening of the aqueousmethanolic extract of $\mathrm{POL}_{4}$ and its components have shown the presence of flavonoids, tannins, saponins, alkaloids, anthraquinones and coumarins.

\section{Total phenolic and flavonoid contents}

Total phenolic and flavonoid contents of the aqueousmethanolic extract of $\mathrm{POL}_{4}$ and its ingredients have been found in varying proportion. Phenolic contents were found in highest proportion in G. sylvestre followed by $\mathrm{Ci} . \mathrm{Cr}>\mathrm{POL}_{4} . \mathrm{Cr}>\mathrm{Ns}$. Cr $>$ Tfg.Cr (Table 1). While flavonoids were found highest in $T$. foenum graecum followed by Gs.Cr $>\mathrm{POL}_{4} . \mathrm{Cr}>\mathrm{Ci} . \mathrm{Cr}>\mathrm{Ns}$.Cr (Table 1).

\section{Effect on blood pressure in anaesthetized rats}

In normotensive anaesthetized SD rats, intravenous administration of polyherbal formulation $\left(\mathrm{POL}_{4}\right)$ and its ingredients (C. intybus, G. sylvestre, N. sativa and T. foenum graecum) caused a dose-dependent $(1,3,10,30$ and $100 \mathrm{mg} / \mathrm{kg}$ ) fall in MAP (Fig. 1). Verapamil has also decreased MAP dose-dependently $(0.1-10 \mathrm{mg} / \mathrm{kg})$ as seen in Fig. 1. The \% maximum effects $\left(E_{\max }\right)$ of the parent formulation, its ingredients and verapamil at respective 
Table 1 Total phenolic and flavonoid contents of $\mathrm{POL}_{4}$ and its ingredients

\begin{tabular}{lcc}
\hline Test materials & $\begin{array}{l}\text { Total phenolic contents } \\
\text { (mg GAE/g of extract) }\end{array}$ & $\begin{array}{l}\text { Total flavonoid contents } \\
\text { (mg QE/g of extract) }\end{array}$ \\
\hline POL $_{4} \cdot \mathrm{Cr}$ & $18.56 \pm 1.0$ & $66.68 \pm 0.87$ \\
$\mathrm{Ns} . \mathrm{Cr}$ & $11.27 \pm 0.76$ & $17.19 \pm 1.52$ \\
$\mathrm{Ci} . \mathrm{Cr}$ & $24.73 \pm 0.20$ & $64.86 \pm 0.86$ \\
$\mathrm{Tfg} . \mathrm{Cr}$ & $10.15 \pm 0.64$ & $87.85 \pm 0.50$ \\
$\mathrm{Gs} . \mathrm{Cr}$ & $39.88 \pm 0.78$ & $75.64 \pm 0.70$
\end{tabular}

Results represent mean \pm SD of 3 measurements

Abbreviations: $\mathrm{POL}_{4} \cdot \mathrm{Cr}$ the crude extract of polyherbal formulation, $\mathrm{Ci} . \mathrm{Cr}$ the crude extract of C. intybus, Gs.Cr the crude extract of G. sylvestre, Ns.Cr the crude extract of $N$. sativa, $T f g . C r$ the crude extract of $T$. foenum graecum, GAE gallic acid equivalent, $Q E$ quercetin equivalent

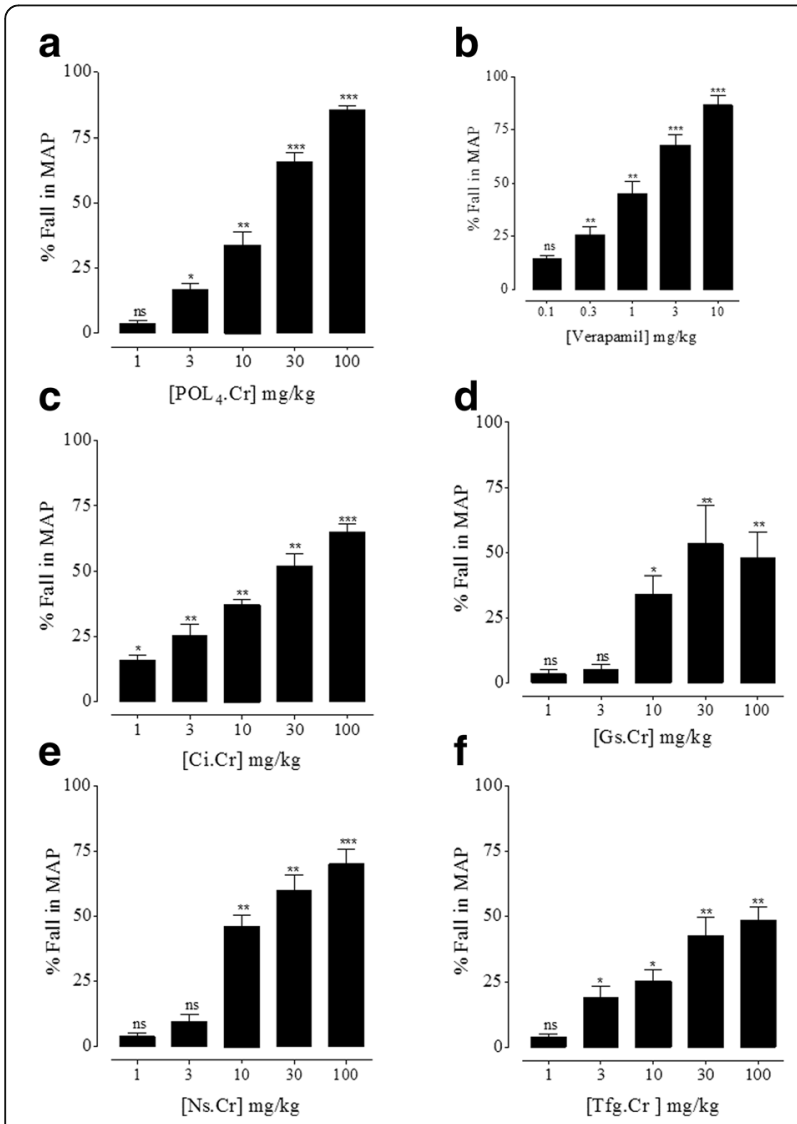

Fig. 1 Blood pressure lowering effect of (a) the crude extract of polyherbal formulation ( $\mathrm{POL}_{4} . \mathrm{Cr}$ ), (b) verapamil, (c) the crude extracts of C. intybus (Ci.Cr), (d) G. sylvestre (Gs.Cr), (e) N. sativa (Ns.Cr) and (f) T. foenum graecum (Tfg.Cr) in normotensive anesthetized rats. The data depicts mean \pm SEM of 3 to 5 individual experiments using 7 to 10 animals. ns, non-significant, ${ }^{*} p<0.05,{ }^{* *} p<0.01$ and ${ }^{* * *} p<$ $0.001 \mathrm{vs}$ saline $(0.1 \mathrm{ml} / \mathrm{kg})$ used as control (One-way ANOVA followed by Dunnett's test) tested concentrations have been listed together in Table 2 . The parent formulation has been found the most effective followed by Ns.Cr $\cong \mathrm{Ci}$.Cr $>\mathrm{Tfg}$.Cr $>$ Gs.Cr.

\section{Effect on isolated rat aortic preparation}

The vasomodulatory effect of parent polyherbal formulation $\left(\mathrm{POL}_{4}\right)$ and its ingredients (C. intybus, G. sylvestre, $N$. sativa and $T$. foenum graecum) were tested against high $\mathrm{K}^{+}(80 \mathrm{mM})$ and P.E $(1 \mu \mathrm{M})$-induced contractions, while to determine the presence of vasospastic activity, test materials were challenged on stabilized basal tone of isolated rat aortic preparations. Against P.E-induced contractions, $\mathrm{POL}_{4}, \mathrm{G}$. sylvestre and $N$. sativa have shown dual activities, initially vasoconstriction at $0.01-$ $1 \mathrm{mg} / \mathrm{ml}$ followed by relaxation at $3-10 \mathrm{mg} / \mathrm{ml}$. However, C. intybus and T. foenum graecum caused complete relaxation of P.E-induced contractions at $0.03-10 \mathrm{mg} / \mathrm{ml}$, similar to the activity pattern of verapamil $(0.03-3 \mu \mathrm{M})$ as seen in Fig. 2. The summary of vasomodulatory effects of $\mathrm{POL}_{4}$ and its ingredients has been shared in upper panel of Table 3. Against high $\mathrm{K}$ ${ }^{+}$-induced contractions, the parent formulation and its ingredients caused inhibition at $0.01-10 \mathrm{mg} / \mathrm{ml}$, similar to the effect of verapamil at $0.03-3 \mu \mathrm{M}$ as shown in Fig. 2. Their respective $\mathrm{EC}_{50}$ values are presented in Table 3. When tested on basal/resting tone of rat aorta, except $T$. foenum graecum which showed activity pattern as of verapamil, the parent formulation and its constituents exhibited vasoconstriction at higher concentrations similar to the effect of phenylephrine. When reproduced in tissues pretreated with phentolamine $(1 \mu \mathrm{M})$, the observed vasocontractile effects were found attenuated as seen in Fig. 3. The \% age maximum vasoconstriction $\left(\mathrm{V}_{\max }\right)$ of $\mathrm{POL}_{4}$ and its elements in the absence and presence of phentolamine has been listed in Table 4 .

To confirm the $\mathrm{Ca}^{++}$antagonist like activity, when the CRCs of $\mathrm{Ca}^{++}$were constructed in the absence and presence of increasing concentrations of $\mathrm{POL}_{4}$ and its

Table 2 Percentage maximum drop in blood pressure $\left(\% E_{\max }\right)$ by the test materials in normotensive anesthetized rats

\begin{tabular}{lll}
\hline Test materials & Concentration & $E_{\max }$ \\
\hline $\mathrm{POL}_{4} \cdot \mathrm{Cr}$ & $100(\mathrm{mg} / \mathrm{ml})$ & $85.33 \pm 1.76(n=4)$ \\
Verapamil & $10(\mu \mathrm{M})$ & $86.66 \pm 4.41^{\mathrm{ns}}(n=4)$ \\
$\mathrm{Ci} . \mathrm{Cr}$ & $100(\mathrm{mg} / \mathrm{ml})$ & $65.00 \pm 2.88^{* *}(n=3)$ \\
$\mathrm{Gs} . \mathrm{Cr}$ & $30(\mathrm{mg} / \mathrm{ml})$ & $53.33 \pm 14.53^{* *}(n=5)$ \\
$\mathrm{Ns} . \mathrm{Cr}$ & $100(\mathrm{mg} / \mathrm{ml})$ & $70.00 \pm 5.77^{* *}(n=5)$ \\
Tfg.Cr & $100(\mathrm{mg} / \mathrm{ml})$ & $48.5 \pm 5.00^{* *}(n=4)$ \\
\hline
\end{tabular}

Data represents mean \pm SEM of 3 to 5 experiments. ns, non-significant, ${ }^{* *} p<0.01$ vs $\mathrm{POL}_{4}$. Cr (One-way ANOVA followed by Dunnett's test) Abbreviations: $\mathrm{POL}_{4}$. Cr the crude extract of poly herbal formulation, $\mathrm{Ci} . \mathrm{Cr}$ the crude extract of C. intybus, Gs.Cr the crude extract of G. sylvestre, Ns.Cr the crude extract of $N$. sativa, $\mathrm{Tfg} . \mathrm{Cr}$ the crude extract of $T$. foenum graecum 


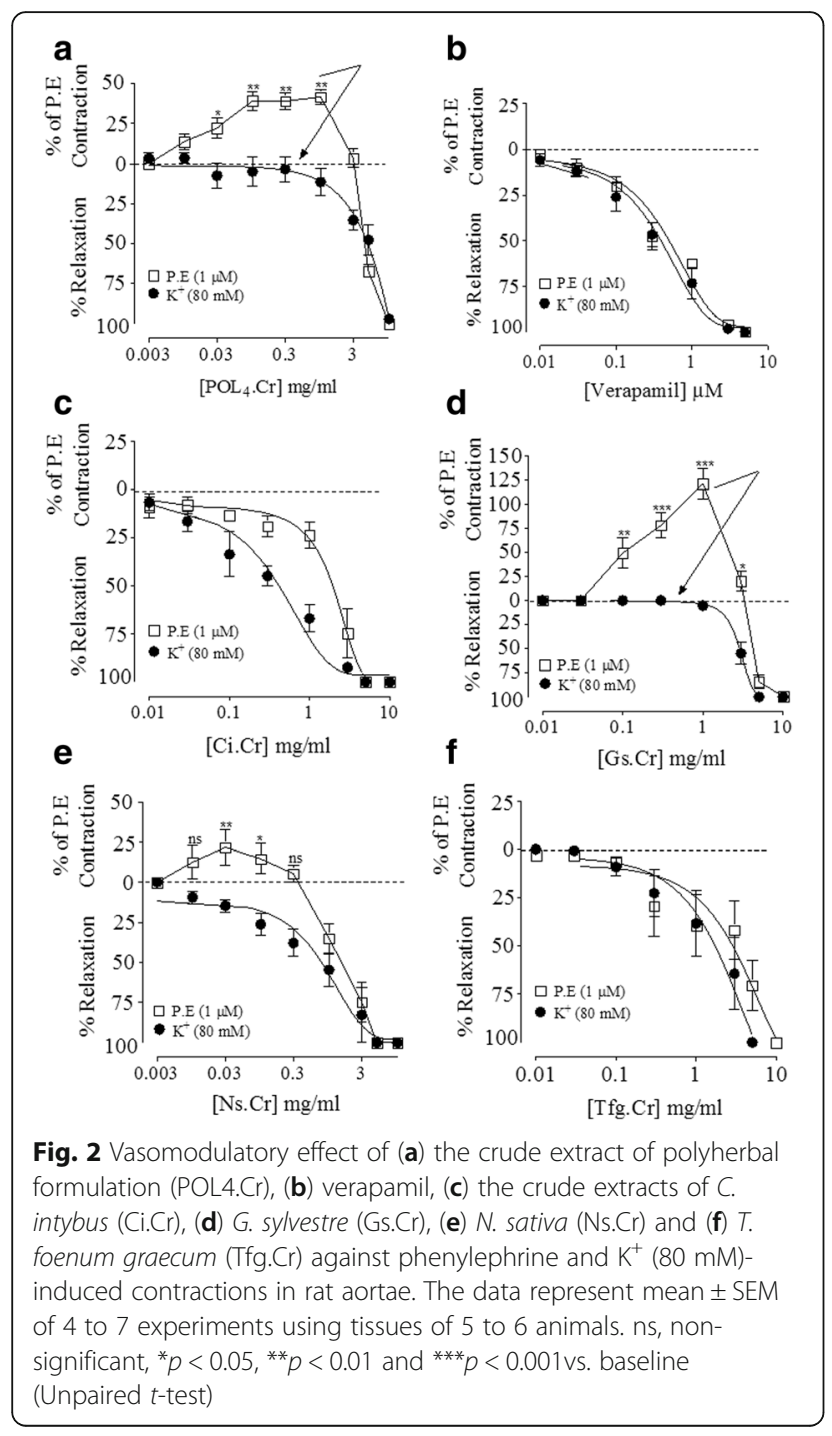

components, these produced a non-parallel rightward shift in the concentration-related curves of $\mathrm{Ca}^{++}$with suppression of maximum effect at concentrations range of $0.03-5 \mathrm{mg} / \mathrm{ml}$, similar to verapamil $(0.03$ and $0.1 \mu \mathrm{M})$ as seen in Fig. 4. The maximum contractions of $\mathrm{Ca}^{++}$at highest concentration in the absence and presence of respective test material(s) is presented in Table 5.

\section{Effect on isolated guinea-pig atria}

In isolated guinea-pig atria, the parent formulation and three of its constituents (C. intybus, G. sylvestre and T. foenum graecum) completely depressed the force and rate of spontaneously beating atria at concentrations range $(0.1-10 \mathrm{mg} / \mathrm{ml})$ as shown in Fig. $5 \mathrm{a}$ and b, similar to verapamil which also inhibited the force and rate of atrial contraction at 0.01 to $1 \mu \mathrm{M}$ (Fig. 5c). However, $N$. sativa initially showed mild cardiac stimulation in terms of an increase in the force of contraction followed by inhibition, while no accelerating effect was observed on the rate of contraction of atria as seen in Fig. 5b. Table 6 shows respective $\mathrm{EC}_{50}$ values of parent formulation and its ingredients against force and rate of contractions of the isolated atrial tissues.

\section{Discussion}

On account of the medicinal use of $\mathrm{POL}_{4}$ and its the ingredients in cardiometabolic disorders like diabetes and associated hypertension [17], when tested in anesthetized rats, $\mathrm{POL}_{4}$ and its ingredients attenuated the mean arterial pressure (MAP) in a dose-dependent manner. Interestingly, the parent formulation was found the most effective followed by $\mathrm{Ns} . \mathrm{Cr} \cong \mathrm{Ci}$. Cr $>\mathrm{Tfg}$. $\mathrm{Cr}>$ Gs.Cr. Our findings on the part of $N$. sativa are in line with earlier report on its antihypertensive efficacy [32]. However, this study is reporting for the first time, the

Table 3 Percentage maximum vasoconstriction $\left(\% \mathrm{~V}_{\max }\right)$ and $\mathrm{EC}_{50}$ values of the test materials against $\mathrm{P}$. E or $\mathrm{K}^{+}(80 \mathrm{mM})$-induced contractions in rat aortic preparations

\begin{tabular}{|c|c|c|c|c|c|c|}
\hline \multirow[t]{2}{*}{ Parameters } & \multicolumn{6}{|l|}{ Test materials } \\
\hline & $\mathrm{POL}_{4} \cdot \mathrm{Cr}$ & Verapamil & $\mathrm{Ci} . \mathrm{Cr}$ & Gs. Cr & Ns. Cr & Tfg. $\mathrm{Cr}$ \\
\hline \multicolumn{7}{|l|}{$\begin{array}{l}\text { Effect against P.E }(1 \mu \mathrm{M}) \text {-induced } \\
\text { contractions }\end{array}$} \\
\hline$\% V_{\max } /$ Conc. $(\mathrm{mg} / \mathrm{ml})$ & $141.43 \pm 4.63 / 1$ & - & - & $221.66 \pm 15.89^{* * *} / 1$ & $131.95 \pm 6.95 * / 0.03$ & - \\
\hline $\begin{array}{l}\text { Complete inhibition with resultant } \\
\mathrm{EC}_{50} \text { values with } 95 \% \text { confidence } \\
\text { interval }\end{array}$ & - & $\begin{array}{l}0.417 \mathrm{mg} / \mathrm{ml} \\
(0.31-0.54)\end{array}$ & $\begin{array}{l}2.01 \mathrm{mg} / \mathrm{ml} \\
(1.62-2.49)\end{array}$ & - & - & $\begin{array}{l}2.29 \mathrm{mg} / \mathrm{ml} \\
(1.15-4.56)\end{array}$ \\
\hline \multicolumn{7}{|l|}{$\begin{array}{l}\text { Effect against } \mathrm{K}^{+}(80 \mathrm{mM}) \text {-induced } \\
\text { contractions }\end{array}$} \\
\hline $\begin{array}{l}\text { Complete inhibition with resultant } \\
\mathrm{EC}_{50} \text { values }\end{array}$ & $\begin{array}{l}4.70 \mathrm{mg} / \mathrm{ml} \\
(3.94-5.60)\end{array}$ & $\begin{array}{l}0.27 \mathrm{mg} / \mathrm{ml} \\
(0.18-0.39)\end{array}$ & $\begin{array}{l}0.31 \mathrm{mg} / \mathrm{ml} \\
(0.19-0.52)\end{array}$ & $\begin{array}{l}3.13 \mathrm{mg} / \mathrm{ml} \\
(2.15-4.56)\end{array}$ & $\begin{array}{l}0.68 \mathrm{mg} / \mathrm{ml} \\
(0.41-1.14)\end{array}$ & $\begin{array}{l}1.40 \mathrm{mg} / \mathrm{ml} \\
(0.91-2.15)\end{array}$ \\
\hline
\end{tabular}

Data represents mean \pm SEM of 4 to 7 experiments

Abbreviations: $\mathrm{POL}_{4} . \mathrm{Cr}$ the crude extract of poly herbal formulation, $\mathrm{Ci} . \mathrm{Cr}$ the crude extract of $\mathrm{C}$. intybus, Gs.Cr the crude extract of G. sylvestre, Ns.Cr the crude extract of $N$. sativa, $\mathrm{Tfg} . \mathrm{Cr}$ the crude extract of $T$. foenum graecum

${ }^{*} p<0.05$ and ${ }^{* * *} p<0.001$ vs. $\mathrm{POL}_{4} \cdot \mathrm{Cr}$ (Unpaired $t$-test) 

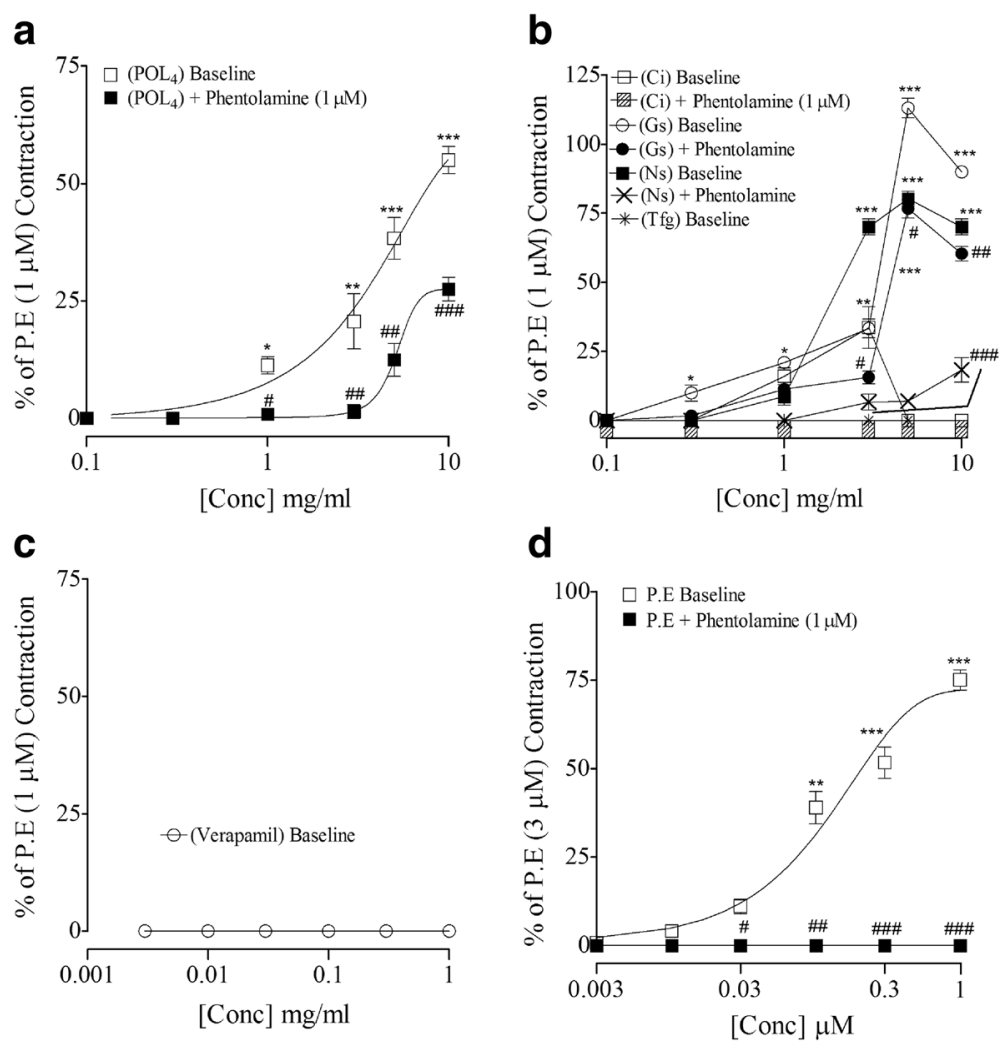

Fig. 3 Vasoconstrictor effect of (a) $\mathrm{POL}_{4}$.Cr, (b) its ingredients, (c) verapamil and (d) phenylephrine (P.E) without and with phentolamine on basal tone of rat aortae. The data show mean \pm SEM of 4 to 8 experiments using tissues of 4 to 5 animals. ${ }^{*} p<0.05,{ }^{* *} p<0.01$ and ${ }^{* * *} p<0.001$ vs. baseline effects, while ${ }^{\#} p<0.05$, ${ }^{\# \#} p<0.01$ and ${ }^{\# \# \#} p<0.001$ vs. vasoconstriction in the presence of phentolamine (Unpaired t-test). Abbreviations: $\mathrm{POL}_{4}$.Cr, the crude extract of poly-herbal formulation; $\mathrm{Ci}$, the crude extract of $C$. intybus; Gs, the crude extract of G. sylvestre; Ns, the crude extract of N. sativa; Tfg, the crude extract of T. foenum graecum

blood pressure lowering efficacy of C. intybus and G. sylvestre in normotensive rats. These findings are also providing a rationale to their medicinal use as cardiotonic or hypotensive $[17,19]$. The blood pressure lowering effects are also in agreement with the prior findings related to vasorelaxant mechanisms on the part of $C$. intybus [27] and T. foenum graecum [30, 31], which might be playing a pivotal role in overall effectiveness of these plants in hypertension. On the contrary, Preuss et al. [44] reported that G. sylvestre did not show antihypertensive effect in spontaneously hypertensive rats, however, we did find its efficacy but with varying pattern

Table 4 Percentage maximum vasoconstriction $\left(\% V_{\max }\right)$ of test materials without and with phentolamine in rat aortic tissues

\begin{tabular}{|c|c|c|c|}
\hline Test materials & Concentration producing $V_{\max }$ & $\% \mathrm{~V}_{\max }$ without phentolamine & $\% \mathrm{~V}_{\max }$ with phentolamine $(1 \mu \mathrm{M})$ \\
\hline $\mathrm{POL}_{4} \cdot \mathrm{Cr}$ & $10(\mathrm{mg} / \mathrm{ml})$ & $55 \pm 2.88$ & $27.5 \pm 2.50^{\# \# \#}$ \\
\hline Ci.Cr & $3(\mathrm{mg} / \mathrm{ml})$ & $33.66 \pm 7.53^{* *}$ & Blocked ${ }^{\# \#}$ \\
\hline Gs.Cr & $3(\mathrm{mg} / \mathrm{ml})$ & $113 \pm 3.51^{* * *}$ & $76.66 \pm 3.33^{\# \# \#}$ \\
\hline Ns.Cr & $5(\mathrm{mg} / \mathrm{ml})$ & $80.33 \pm 2.60^{* *}$ & $18.33 \pm 4.41^{\# \# \#}$ \\
\hline Tfg.Cr & Did not exhibited any vasoconstriction & & \\
\hline Verapamil & Did not exhibited any vasoconstriction & & \\
\hline P.E & $1(\mu \mathrm{M})$ & $75.19 \pm 2.16^{* * *}$ & Blocked \#\#\# \\
\hline
\end{tabular}

Data represents mean \pm SEM of 4 to 8 experiments

Abbreviations: $\mathrm{POL}_{4} . \mathrm{Cr}$ the crude extract of poly herbal formulation, $\mathrm{Ci}$.Cr the crude extract of $\mathrm{C}$. intybus, Gs.Cr the crude extract of $\mathrm{G}$. sylvestre, Ns.Cr the crude extract of N. sativa, $\mathrm{Tfg}$. Cr the crude extract of $T$. foenum graecum, P.E Phenylephrine

ns, non-significant, $* * 0<0.01$ and ${ }^{* * * * \# \# p} p<0.001$

* shows a comparison of $\% \mathrm{~V}_{\text {max }}$ of test materials without phentolamine vs. $\mathrm{POL}_{4} \cdot \mathrm{Cr}$ (One-way ANOVA followed by Dunnett's test), while \# shows a comparison between $\% \mathrm{~V}_{\max }$ values without phentolamine vs. respective $\% \mathrm{~V}_{\max }$ values with phentolamine (Unpaired $t$-test) 

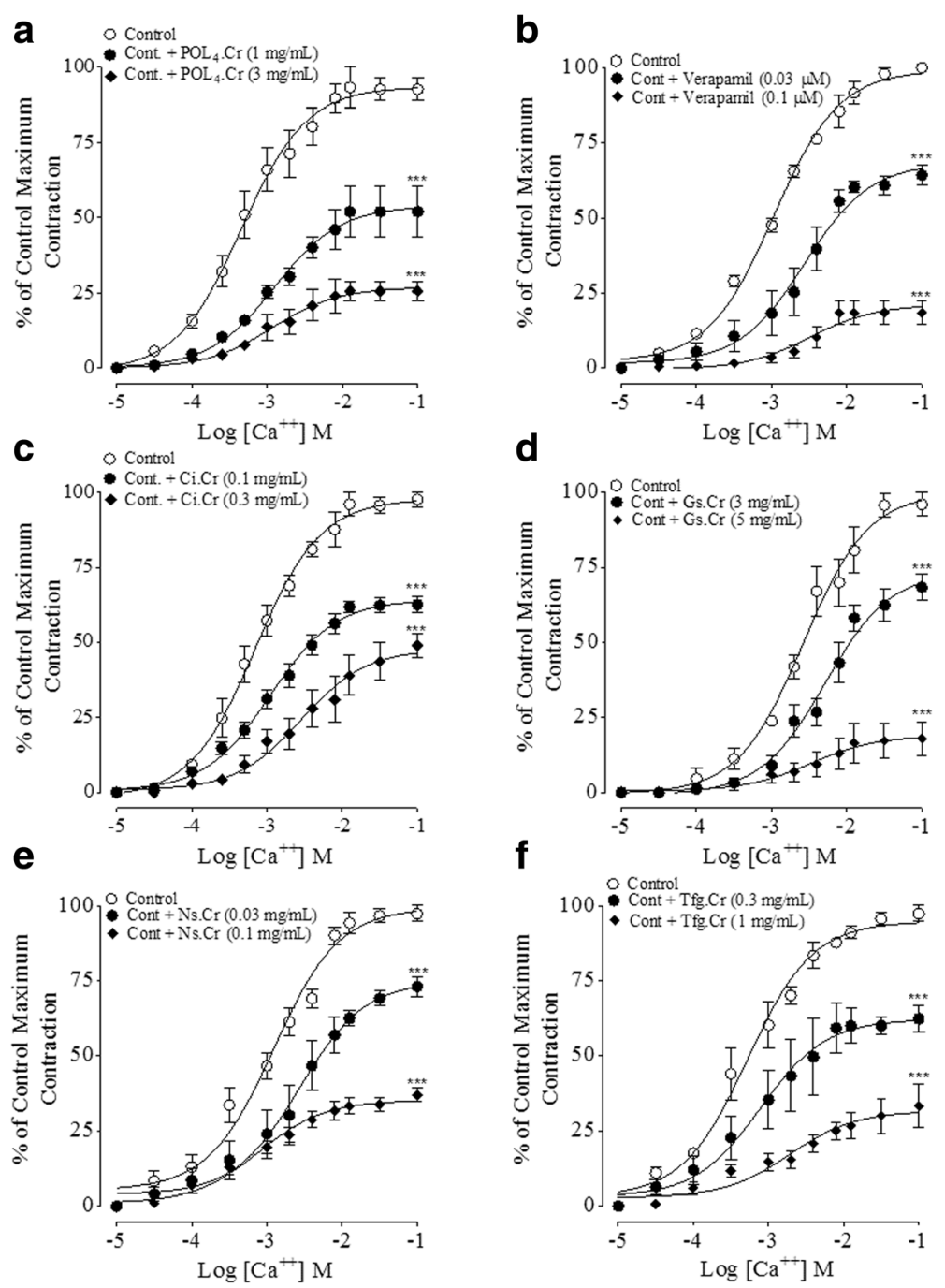

Fig. 4 Concentration-response curves of $\mathrm{Ca}^{++}$constructed in absence and presence of (a) the crude extract of polyherbal formulation (POL4.Cr), (b) verapamil, (c) the crude extracts of C. intybus (Ci.Cr), (d) G. sylvestre (Gs.Cr), (e) N. sativa (Ns.Cr) and (f) T. foenum graecum (Tfg.Cr) in rat aortae. The data denote mean \pm SEM of 4 to 7 experiments using tissues of 4 to 6 animals ${ }^{* * *} p<0.001$ vs. Control CRCs of Ca ${ }^{++}$(Two-way analysis of variance (ANOVA) followed by Bonferroni's post-test correction)

in normotensive rats which needs further investigations using multiple models and species to attest or oppose its therapeutic utility in hypertension.

Blood pressure is the product of cardiac output and peripheral resistance [45]. An increase in any of these two determinants can develop hypertension. Antihypertensive drugs target both components either alone or in combination. The preferred approach would be to cause a predominantly reduction in peripheral vascular resistance along with cardiac output.

To explore the effect of parent formulation and its components on vascular resistance, in pre-contracted rat aortic preparations, $\mathrm{POL}_{4}$ and its ingredients caused inhibition of $\mathrm{K}^{+}(80 \mathrm{mM})$-induced contractions, where
Ci.Cr was found the most potent followed by Ns.Cr $>$ $\mathrm{Tfg}$. $\mathrm{Cr}>\mathrm{Gs} . \mathrm{Cr} \cong \mathrm{POL}_{4}$. Based on inhibitory effects of test material(s) against $\mathrm{K}^{+}(80 \mathrm{mM})$-induced contractions, to further attest the presence of $\mathrm{Ca}^{++}$antagonist like activity on the part of test material(s), the concentrationresponse curves (CRCs) of $\mathrm{Ca}^{++}$were constructed in the absence and presence of different concentrations of $\mathrm{POL}_{4}$ and its ingredients, respectively. All produced a non-parallel rightward shift in CRCs of $\mathrm{Ca}^{++}$with suppression of the maximum effect, similar to activity pattern of verapamil, a known $\mathrm{Ca}^{++}$antagonist [46]. Against phenylephrine (P.E)- induced contraction, C. intybus and T. foenum graecum showed complete relaxation, however, $\mathrm{POL}_{4}, G$. sylvestre and N. sativa showed initially 
Table 5 Percentage maximal response of $\mathrm{Ca}^{++}\left(\% \mathrm{E}_{\max }\right)$ without and with test materials in rat aortic tissues

\begin{tabular}{llcl}
\hline Test materials & Concentration & $\begin{array}{c}\% E_{\max } \text { of } \mathrm{Ca}^{++} \pm \\
\mathrm{SEM}, n=4-7\end{array}$ & $P$ value \\
\hline Control & - & $100 \pm 0$ & - \\
$\mathrm{POL}_{4} \cdot \mathrm{Cr}(\mathrm{mg} / \mathrm{ml})$ & 1 & $52.66 \pm 8.62$ & $p<0.001$ \\
& 3 & $25.66 \pm 3.18$ & $p<0.001$ \\
Verapamil $(\mu \mathrm{M})$ & 0.03 & $63.85 \pm 4.00$ & $p<0.001$ \\
& 0.1 & $18.65 \pm 4.09$ & $p<0.001$ \\
Ci.Cr $(\mathrm{mg} / \mathrm{ml})$ & 0.1 & $62.33 \pm 3.84$ & $p<0.001$ \\
& 0.3 & $49.00 \pm 4.00$ & $p<0.001$ \\
Gs.Cr $(\mathrm{mg} / \mathrm{ml})$ & 3 & $68.33 \pm 4.41$ & $p<0.001$ \\
& 5 & $17.93 \pm 5.50$ & $p<0.001$ \\
Ns.Cr $(\mathrm{mg} / \mathrm{ml})$ & 0.03 & $73.00 \pm 3.39$ & $p<0.001$ \\
& 0.1 & $37.00 \pm 2.38$ & $p<0.001$ \\
$\operatorname{Tfg} . \operatorname{Cr}(\mathrm{mg} / \mathrm{ml})$ & 0.3 & $62.33 \pm 4.33$ & $p<0.001$ \\
& 1 & $33.33 \pm 7.26$ & $p<0.001$ \\
& & &
\end{tabular}

$p$-value were obtained by comparing the concentration-response curves of $\mathrm{Ca}$ ${ }^{++}$in the absence (control) and presence of respective test material(s) using two-way analysis of variance (ANOVA) followed by Bonferroni's post-test correction

Abbreviations: $\mathrm{POL}_{4}$. $\mathrm{Cr}$ the crude extract of poly herbal formulation, $\mathrm{Ci} . \mathrm{Cr}$ the crude extract of $\mathrm{C}$. intybus, Gs.Cr the crude extract of G. sylvestre, $\mathrm{Ns.Cr}$ the crude extract of $N$. sativa, $\mathrm{Tfg}$. $\mathrm{Cr}$ the crude extract of $T$. foenum graecum

vasoconstriction followed by relaxation at higher tested concentrations. The inhibitory potential of $\mathrm{POL}_{4}$ and its ingredients against $\mathrm{K}^{+}(80 \mathrm{mM})$ and P.E signify their ability to interfere with $\mathrm{Ca}^{++}$entry through voltagedependent channels (VDCs) and receptor-operated channels (ROCs). This is evident as $\mathrm{K}^{+}(80 \mathrm{mM})$ and P.E $(1 \mu \mathrm{M})$ mediate contraction by influx of extracellular $\mathrm{Ca}$ ${ }^{++}$through VDCs and ROCs, respectively, resulting in increased intracellular $\mathrm{Ca}^{++}$levels trigging sustained contractions [43, 47]. Based on observed (vasoconstrictor and/or vasodilator) effects of test material(s) on P.E-induced contractions, the parent formulation and its ingredients were studied for the presence of vasostimulant activity on the baseline status of isolated rat aortic preparations. All exhibited vasoconstriction with varying efficacy, being Gs.Cr the most potent followed by Ns.Cr $>\mathrm{POL}_{4}>\mathrm{Ci}$.Cr), similar to the effect of phenylephrine. However, T. foenum graecum was devoid of any vasoconstriction, similar to the effect of verapamil. When these effects were studied in the presence of phentolamine, an $\alpha$ - adrenergic antagonist, all showed partial sensitivity to phentolamine except $C$. intybus which was found completely phentolamine-sensitive. These data suggest the presence of multiple types of vasoconstrictor constituents like phentolamine sensitive and insensitive, which needs further studies to characterize. It was interesting to note that despite the presence of vasoconstrictor constituents both in parent formulation and most of its ingredients, these did not increase blood pressure in anaesthetized rats, which might be because of the dominant role of endogenous mediators in intact body systems offering blockade to vasoconstrictor constituents. On the other hand, the coexistence of strong vasorelaxant and cardio depressant elements in the parent formulation and its ingredients may not be allowing the expression of vasoconstrictor elements to dominate and cause hypertension in the in vivo system.

To determine cardio-suppressant activity contributing in attenuating cardiac output, when the parent formulation and its ingredients were tested on spontaneously beating atrial preparations of guinea-pigs, $\mathrm{POL}_{4}$ and three of its ingredients showed exclusively negative inotropic and chronotropic effects similar to the effect of verapamil. However, N. sativa showed mild cardiac stimulation in terms of an increase in the force of contraction, which is also in support to its medicinal use as cardiac stimulant in the form of a formulation (LububAl-Asrar) [16]. The probable mechanism likely to be involved in cardio-depressant activities seems $\mathrm{Ca}^{++}$antagonist pathway, while mild cardiac stimulant effect on the part of $N$. sativa needs further exploration to confirm. The standard $\mathrm{Ca}^{++}$antagonist like verapamil which is known to lower blood pressure $[48,49]$ partly by causing cardiac suppression via inhibition of inward slow current at the time of action potential [50]. The observed cardiac inhibitory effect of the test material(s) might be attenuating cardiac output leading to a decrease in the blood pressure. Our findings are in line with the cardiac inhibitory effect of medicinal plants causing reduction in the cardiac output, thus resulting in decreased blood pressure [15, 43, 51-53]. In summary, it appears that nature has composed the opposing mechanisms not allowing the vasodilator effect to cross the desired limit thus overriding excessive drop in blood pressure, which has usually been observed when using standard antihypertensive drugs [45]. The co-existence of components with combating activities have been found common in many plants like Viola odorata [43], Carthamus oxycantha [47], Curcuma long [54], Acorus calamus [55] and piperine, an alkaloid of Piper longum and Piper nigrum [56] and is also in agreement with the concept that natural products in their original form possess synergistic and/or side effects nullifying combinations [11]. Varied distribution of total phenolic and flavonoid in $\mathrm{POL}_{4}$ and its constituents is also providing strength to their cardiovascular benefits as phenolic and flavonoids are known for their effectiveness in cardiovascular disorders $[50,57,58]$. On the other hand, these findings suggest that excluding G. sylvestre from $\mathrm{POL}_{4}$ formulation may result in a better product with improved efficacy in treating hypertension. 


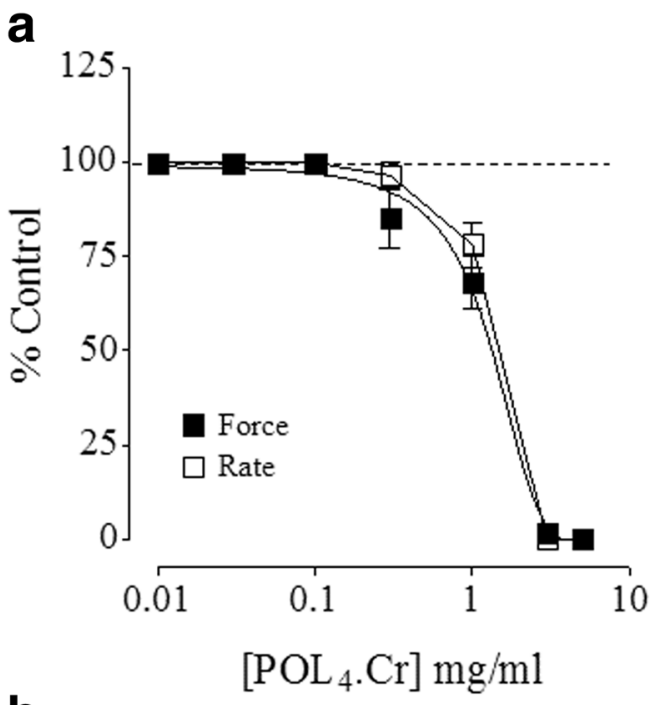

b

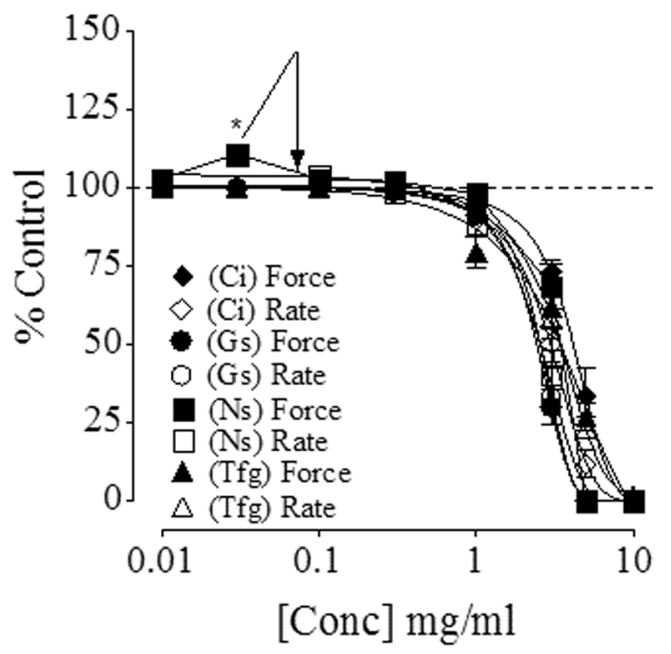

C

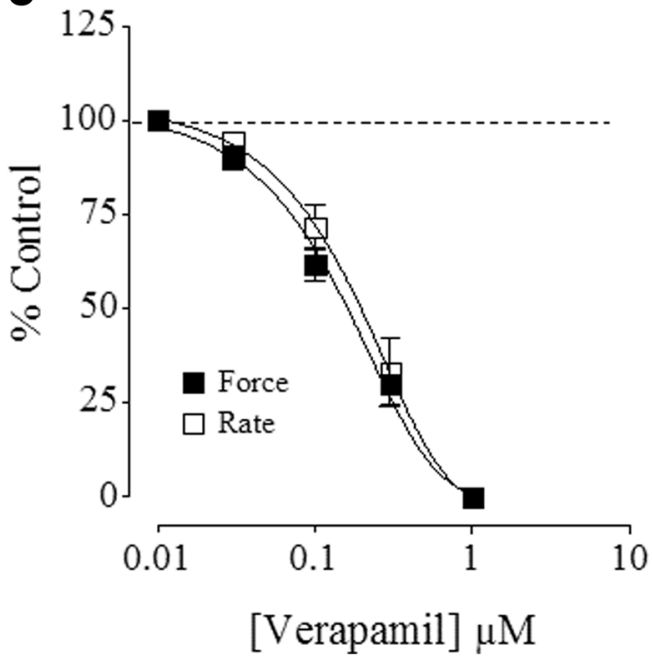

Fig. 5 Modulatory effect of (a) $\mathrm{POL}_{4}$. $\mathrm{Cr}$, (b) its ingredients and (c) verapamil on force and rate of contraction in isolated guinea-pig atria. Data represent mean \pm SEM of 3 to 7 individual experiments using tissues of 4 to 6 animals. ${ }^{*} p<0.05 \mathrm{vs}$ control (Unpaired $t$-test). Abbreviations: $\mathrm{POL}_{4}$.Cr, the crude extract of polyherbal formulation; $\mathrm{Ci}$, the crude extract of $\mathrm{C}$. intybus; $\mathrm{Gs}$, the crude extract of $\mathrm{G}$. sylvestre; Ns, the crude extract of N. sativa; Tfg, the crude extract of $T$.

foenum graecum

\section{Conclusions}

This study indicates that $\mathrm{POL}_{4}$ and its ingredients possess blood pressure lowering effect predominantly mediated through inhibition of $\mathrm{Ca}^{++}$influx via membranous $\mathrm{Ca}^{++}$channels and receptor ( $\alpha$-adrenergic) operated pathways. The additional presence of vasoconstrictor agents (partially phentolamine-sensitive) in parent formulation possibly because of $G$. sylvestre and $N$. sativa may be meant to suppress the excessive hypotension, a known adverse effect associated with the use of antihypertensive drugs when used at higher doses and/or for longer duration. Thus, this study provides a rationale to the medicinal use of $\mathrm{POL}_{4}$ and its ingredients in cardiovascular disorders like hypertension.

\section{Abbreviations}

ACh: Acetylcholine; CCB: $\mathrm{Ca}^{++}$channel blockade; Cl: Confidence interval; Ci.Cr: Aqueous methanolic extract of Cichorium intybus; CRCs: Concentrationresponse curves; $\mathrm{EC}_{50}$ : Effective concentration producing $50 \%$ effect; Gs.Cr: Aqueous methanolic extract of Gymnema sylvestre; High $\mathrm{K}^{+}: \mathrm{K}^{+}$ (80 mM); i.p: intraperitoneally; MAP: Mean arterial pressure; Ns.Cr: Aqueous methanolic extract of Nigella sativa; $\mathrm{POL}_{4}$.Cr: Aqueous methanolic extract of polyherbal formulation; ROCs: Receptor-operated channels; Tfg.Cr: Aqueous methanolic extract of Trigonella foenum graecum; VDCs: Voltage-dependent channels

\section{Acknowledgements}

The study was carried out during elective rotation of Mr. Abdul Malik as research volunteer, working under supervision of Dr. Malik Hassan Mehmood at Department of Biological and Biomedical Sciences (BBS). We would like to thank Animal Facility staff members for their help in animal experiment. We would like to express our sincere gratitude to Department of BBS and the

Table $6 \mathrm{EC}_{50}$ values of the test materials against force and rate of contractions in guinea-pig atria

\begin{tabular}{|c|c|c|}
\hline Test materials & $\begin{array}{l}\text { Force (inhibition) with resultant } \\
\text { EC }_{50} \text { values with } 95 \% \text { confidence } \\
\text { interval/Mean } \pm \text { SEM, } n=3-7\end{array}$ & $\begin{array}{l}\text { Rate (inhibition) with } \\
\text { resultant } \mathrm{EC}_{50} \text { values, } \\
n=3-7\end{array}$ \\
\hline $\mathrm{POL}_{4} \mathrm{Cr}$ & $1.28 \mathrm{mg} / \mathrm{ml}(1.08-1.52)$ & $1.22 \mathrm{mg} / \mathrm{ml}(0.70-2.15)$ \\
\hline Verapamil & 0.14 mg/ml (0.11-0.83) & $0.19 \mathrm{mg} / \mathrm{ml}(0.15-0.24)$ \\
\hline $\mathrm{Ci} \cdot \mathrm{Cr}$ & $4.18 \mathrm{mg} / \mathrm{ml}(3.92-4.46)$ & $3.16 \mathrm{mg} / \mathrm{ml}(2.95-3.39)$ \\
\hline Gs.Cr & $2.47 \mathrm{mg} / \mathrm{ml}(2.24-2.72)$ & $3.16 \mathrm{mg} / \mathrm{ml}(3.03-3.30)$ \\
\hline Ns.Cr & $\begin{array}{l}\text { Mild cardiac stimulation } \\
(110.66 \pm 2.33 \%) \text { at } 0.03 \\
\mathrm{mg} / \mathrm{ml} \text { followed by } \\
\text { inhibition at } 1-10 \mathrm{mg} / \mathrm{ml} \text {. }\end{array}$ & $2.47 \mathrm{mg} / \mathrm{ml}(2.06-2.95)$ \\
\hline Tfg.Cr & 3.65 mg/ml (3.21-4.16) & $3.516 \mathrm{mg} / \mathrm{ml}(3.23-3.82)$ \\
\hline
\end{tabular}

Abbreviations: $\mathrm{POL}_{4} \cdot \mathrm{Cr}$ the crude extract of poly herbal formulation, $\mathrm{Ci} . \mathrm{Cr}$ the crude extract of C. intybus, Gs.Cr the crude extract of G. sylvestre, Ns.Cr the crude extract of $\mathrm{N}$. sativa, $\mathrm{Tfg} . \mathrm{Cr}$ the crude extract of $T$. foenum graecum 
Aga Khan University for providing funding from Research Module Project Funds and Seed Money Grant. We would like to thank Dr Nauman Aziz for his continuous guidance and helping us to provide test material.

\section{Funding}

This study was supported by the Department of Biological and Biomedical Sciences through Research Module Project Funds allocated for undergraduate students and the Aga Khan University through Seed Money Research Grant award

\section{Availability of data and materials}

The data and materials of this article are included within the article.

\section{Authors' contributions}

MHM designed the project, supervised the study and drafted final manuscript. AM and HC carried out literature search, experimental work and data acquisition. AHG and MSA contributed in study design and review of the manuscript for publication. All authors read and approved the final manuscript for publication.

\section{Competing interests}

The authors declare that they have no competing interests.

\section{Consent for publication}

Not applicable.

\section{Ethics approval}

The animals were used with due care and as per the experimental protocols described and approved by Ethics Committee for Animal Care and Use (ECACU) of the Aga Khan University, Karachi (approval number 57-ECACU-BBS-15).

\section{Author details}

${ }^{1}$ Natural Product Research Division, Department of Biological and Biomedical Sciences, Faculty of Health Sciences, Medical College, The Aga Khan University, Stadium Road, P.O. Box 3500, Karachi 74800, Pakistan. ${ }^{2}$ Faculty of Pharmacy, University of Sargodha, Sargodha 40100, Pakistan. ${ }^{3}$ The Aga Khan University Medical College, Stadium Road, P.O. Box 3500, Karachi 74800, Pakistan. ${ }^{4}$ Pakistan Council for Science and Technology, G-5/2, Islamabad 44000, Pakistan

\section{Received: 19 July 2016 Accepted: 21 February 2017}

Published online: 07 March 2017

\section{References}

1. Deaton C, Froelicher ES, Wu LH, Ho C, Shishani K, Jaarsma T. The global burden of cardiovascular disease. Eur J Cardiovasc Nurs. 2011;10:S5-13.

2. Whelton PK, He J, Appel LJ. National high blood pressure education program coordinating committee: primary prevention of hypertension: clinical and public health advisory from the national high blood pressure education program. JAMA. 2002;288:1882-8.

3. Alwan A. Global status report on non-communicable diseases. Geneva: WHO; 2010. p. 2-17.

4. Shah SM, Loney $T$, Sheek-Hussein M, Sadig M, Dhaheri S, Barazi I, et al. Hypertension prevalence, awareness, treatment, and control, in male South Asian immigrants in the United Arab Emirates: a cross-sectional study. BMC Cardiovasc Disord. 2015;15:1

5. Almas A, Ehtamam A, Khan AH. Spectrum of antihypertensive therapy in South Asians at a tertiary care hospital in Pakistan. BMC Res Notes. 2011;4:318.

6. Hussain Ml, Naqvi BS, Ahmed I, Ali N. Hypertensive patients readiness to use of mobile phones and other information technological modes for improving their compliance to doctors' advice in Karachi. Pak J Med Sci. 2015;31:9.

7. Vrijens B, Vincze G, Kristanto P, Urquhart J, Burnier M. Adherence to prescribed antihypertensive drug treatments: longitudinal study of electronically compiled dosing histories. BMJ. 2008;336:1114-7.

8. Baharvand-Ahmadi B, Bahmani M, Eftekhari Z, Jelodari M, Mirhoseini M. Overview of medicinal plants used for cardiovascular system disorders and diseases in ethnobotany of different areas in Iran. JHP. 2016;5.

9. Yao LH, Jiang Y, Shi J, Tomas-Barberan F, Datta N, Singanusong R, Chen S. Flavonoids in food and their health benefits. Plant Food Hum Nutr. 2004;59:113-22.
10. Ekor $M$. The growing use of herbal medicines. issues relating to adverse reactions and challenges in monitoring safety. Front Pharmacol. 2014:4:177.

11. Gilani AH. Atta-ur-Rehman.Trends in ethnopharmacology. J Ethnopharmacol. 2005;100:43-9.

12. Mehmood MH, Munir S, Khalid UA, Asrar M, Gilani AH. Antidiarrhoeal, antisecretory and antispasmodic activities of Matricaria chamomilla are mediated predominantly through $\mathrm{K}^{+}$-channels activation. BMC Complement Altern Med. 2015;15:1.

13. Chaudhary MA, Imran I, Bashir S, Mehmood MH, Rehman N, Gilani AH. Evaluation of gut modulatory and bronchodilator activities of Amaranthus spinosus Linn. BMC Complement Altern Med. 2012;12:166.

14. Ahmad M, Qureshi R, Arshad M, Khan MA, Zafar M. Traditional herbal remedies used for the treatment of diabetes from district Attock (Pakistan). Pak J Bot. 2009;141:2777-82.

15. Aziz N, Mehmood MH, Gilani AH. Studies on two polyherbal formulations (ZPTO and ZTO) for comparison of their antidyslipidemic, antihypertensive and endothelial modulating activities. BMC Complement Altern Med. 2013:13:371.

16. Said HM. Hamdard pharmacopoeia of eastern medicine. Karachi: Hamdard National Foundation; 1970

17. Duke JA, Bogenschutz-Godwin MJ, Du Celliar J, Duke PAK. Handbook of medicinal herbs. 2nd ed. Boca Raton: CRC Press; 2002. p. 88-363.

18. Street RA, Sidana J, Prinsloo G. Cichorium intybus: traditional uses, phytochemistry, pharmacology, and toxicology. Evid Based Complement Alternat Med. 2013;2013:579319.

19. Tiwari P, Mishra BN, Sangwan NS. Phytochemical and pharmacological properties of Gymnema sylvestre: an important medicinal plant. Biomed Res Int. 2014;2014:830285.

20. Khan MA, Afzal M. Chemical composition of Nigella sativa Linn: part 2 recent advances. Inflammopharmacol. 2016;24:1-13.

21. Khorshidian N, Yousefi Asli M, Arab M, Mortazavian AM, Adeli MA. Fenugreek: potential applications as a functional food and nutraceutical. Nutr Food Sci Res. 2016:3:5-16.

22. Gonca E, Kurt Ç. Cardioprotective effect of Thymoquinone: a constituent of Nigella sativa L., against myocardial ischemia/reperfusion injury and ventricular arrhythmias in anaesthetized rats. Pak J Pharm Sci. 2015;28: 1267-73.

23. Randhawa MA, Alghamdi MS, Maulik SK. The effect of thymoquinone, an active component of Nigella sativa, on isoproterenol induced myocardial injury. Pak J Pharm Sci. 2013;26:1215-9.

24. Ghayur MN, Gilani AH, Janssen $\sqcup$. Intestinal, airway, and cardiovascular relaxant activities of thymoquinone. Evid Based Complement Alternat Med. 2012;2012.

25. El-Taher KE, Al-Ajmi MF, Al-Bekairi AM. Some cardiovascular effects of the dethymoquinonated Nigella sativa volatile oil and its major components apinene and p-cymene in rats. SPJ. 2003:11:104-10.

26. Khattab MM, Nagi MN. Thymoquinone supplementation attenuates hypertension and renal damage in nitric oxide deficient hypertensive rats. Phytother Res. 2007;21:410-4.

27. Sakurai N, lizuka T, Nakayama S, Funayama H, Noguchi M, Nagai M. Vasorelaxant activity of caffeic acid derivatives from Cichorium intybus and Equisetum arvense. Yakugaku Zasshi. 2003;123:593-8.

28. Sadeghi N, Dianat M, Badavi M, Malekzadeh A. Cardioprotective effect of aqueous extract of Chichorium intybus on ischemia-reperfusion injury in isolated rat heart. Avicenna J Phytomed. 2015;5:568-75.

29. Kumar V, Bhandari U, Tripathi CD, Khanna G. Evaluation of antiobesity and cardioprotective effect of Gymnema sylvestre extract in murine model. Indian J Pharmacol. 2012:44:607.

30. Balaraman R, Dangwal S, Mohan M. Antihypertensive effect of Trigonella foenum-greacum seeds in experimentally induced hypertension in rats. Pharmaceut Biol. 2006;1(44):568-75.

31. Roghani M, Baluchnejadmojarad T. The role of L-type calcium channels in the vascular effect of Trigonella foenum-graecum $L$. in diabetic rats. DARU J Pharm Sci. 2006;14:1-5

32. Fallah Huseini H, Amini M, Mohtashami R, Ghamarchehre ME, Sadeghi Z, Kianbakht S, Fallah Huseini A. Blood pressure lowering effect of Nigella sativa $\mathrm{L}$. seed oil in healthy volunteers: a randomized, double-blind, placebo-controlled clinical trial. Phytother Res. 2013;27:1849-53.

33. Amin F, Islam N, Anila N, Gilani AH. Clinical efficacy of the co-administration of Turmeric and Black seeds (Kalongi) in metabolic syndrome-A double blind randomized controlled trial-TAK-MetS trial. Complement Ther Med. 2015;23:165-74. 
34. Qidwai W, Hamza HB, Qureshi R, Gilani A. Effectiveness, safety, and tolerability of powdered Nigella sativa (kalonji) seed in capsules on serum lipid levels, blood sugar, blood pressure, and body weight in adults: results of a randomized, double-blind controlled trial. J Altern Complement Med. 2009;15:639-44.

35. Doggrell SA, Brown L. Rat models of hypertension, cardiac hypertrophy and failure. Cardiovasc Res. 1998;39:89-105.

36. Lake KD, Martin BR, Kunos G, Varga K. Cardiovascular effects of Anandamide in anesthetized and conscious normotensive and hypertensive rats. Hypertens. 1997;29:1204-10.

37. Leong $\mathrm{XF}, \mathrm{Ng} \mathrm{CY}$, Jaarin $\mathrm{K}$. Animal models in cardiovascular research: Hypertension and atherosclerosis. Biomed Res Int. 2015;2015.

38. Williamson EM, Okpako DT, Evans FJ. Selection, preparation and pharmacological evaluation of plant material. In: Pharmacological methods in phytotherapy research. 1st ed. Chichester: Wiley; 1996. p. 15-23.

39. Evans WC. Trease and evan's pharmacognosy. 14th ed. London: W.B. Sounders; 1996. p. 161-408. ISBN 0-7020-1899-6.

40. Singleton $\mathrm{VL}$, Orthofer R, Lamuela-Raventos RM. Analysis of total phenols and other oxidation substrates and antioxidants by means of folin-ciocalteu reagent. Methods Enzymol. 1999;299:152-78.

41. Huang DJ, Chun-Der LI, Hsien-Jung CH, Yaw-Huei LI. Antioxidant and antiproliferative activities of sweet potato (Ipomoea batatas [L.] LamTainong 57') constituents. Bot Bull Acad Sin. 2004;45:179-86.

42. Aziz N, Mehmood MH, Siddiqi HS, Sadiq F, Maan W, Gilani AH. Antihypertensive, antidyslipidemic and endothelial modulating activities of Orchis mascula. Hypertens Res. 2009;32:997-1003.

43. Siddiqi HS, Mehmood MH, Rehman NU, Gilani AH. Studies on the antihypertensive and antidyslipidemic activities of Viola odorata leaves extract. Lipids Health Dis. 2012;11:1.

44. Preuss HG, Jarrell ST, Scheckenbach $\mathrm{R}$, Lieberman S, Anderson RA. Comparative effects of chromium, vanadium and Gymnema sylvestre on sugar-induced blood pressure elevations in SHR. J Am Coll Nutr. 1998;17:116-23

45. Johansen PL. Hemodynamic effects of calcium antagonists in hypertension. Calcium Antagonists in Clinical Medicine Philadelphia. 1992. p. 62-98.

46. Godfraind T, Miller R, Wibo M. Calcium antagonism and calcium entry blockade. Pharmacol Rev. 1986;38:321-416.

47. Gilani AH, Bukhari IA, Khan RA, Khan A, Ullah F, Ahmad VU. Cholinomimetic and calcium channel blocking activities of Carthamus oxycantha. Phytother Res. 2005;19:679-83.

48. Fleckenstein A. Specific pharmacology of calcium in myocardium, cardiac pacemakers, and vascular smooth muscle. Annu Rev Pharmacol Toxicol. 1977;17:149-66

49. Karaki H, Ozaki H, Hori M, Mitsui-Saito M, Amano Kl, Harada Kl, et al. Calcium movements, distribution, and functions in smooth muscle. Pharmacol Rev. 1997;49:157-230

50. Roden DM. Antiarrhythmic drugs. Goodman and Gilman's the Pharmacological Basis of Therapeutics. New York: McGraw-Hill; 2006. p. 899-932.

51. Aziz N, Mehmood MH, Mandukhal SR, Bashir S, Raoof S, Gilani AH. Antihypertensive, antioxidant, antidyslipidemic and endothelial modulating activities of polyherbal formulation (POL-10). Vascul Pharmacol. 2009:50:57-64.

52. Khan A, Mustafa MR, Khan AU, Murugan DD. Hypotensive effect of Gentiana floribunda is mediated through $\mathrm{Ca}^{++}$antagonism pathway. BMC Complement Altern Med. 2012;12:121

53. Siddiqi HS, Majeed A, Gilani AH. Pharmacological basis for the medicinal use of Wrightia tinctoria in hypertension and dyslipidemia. J Cardiovasc Pharmacol. 2014;64:151-63.

54. Gilani AH, Shah AJ, Ghayur MN, Majeed K. Pharmacological basis for the use of turmeric in gastrointestinal and respiratory disorders. Life Sci. 2005;76:3089-105

55. Shah AJ, Gilani AH. Blood pressure-lowering and vascular modulator effects of Acorus calamus extract are mediated through multiple pathways. J Cardiovasc Pharmacol. 2009:54:38-46.
56. Taqvi SIH, Shah AJ, Gilani AH. Blood pressure lowering and vasomodulator effects of piperine. J Cardiovasc Pharmacol. 2008;52:452-8.

57. Morand C, Dubray C, Milenkovic D, Lioger D, Martin JF, Scalbert A, Mazur A. Hesperidin contributes to the vascular protective effects of orange juice: a randomized crossover study in healthy volunteers. Am J Clin Nutr. 2011;93:73-80

58. Mannaa FA, Abdel-Wahhab KG, Abdel-Wahhab MA. Prevention of cardiotoxicity of aflatoxin B1 via dietary supplementation of papaya fruit extracts in rats. Cytotechnology. 2014;66:327-34.

\section{Submit your next manuscript to BioMed Central and we will help you at every step:}

- We accept pre-submission inquiries

- Our selector tool helps you to find the most relevant journal

- We provide round the clock customer support

- Convenient online submission

- Thorough peer review

- Inclusion in PubMed and all major indexing services

- Maximum visibility for your research

Submit your manuscript at www.biomedcentral.com/submit
Biomed Central 